\title{
Organ Measurements Specimen Condition
}

National Cancer Institute

\section{Source}

National Cancer Institute. Organ Measurements Specimen Condition. NCI Thesaurus.

Code C119893.

A characteristic that refers to the physical and org anoleptic state of a biospecimen used for an organ measurement. 